\title{
Vulnerability of shipwreck sites in Indonesian waters
}

\author{
Nia Naelul Hasanah Ridwan* \\ Research Institute for Coastal Resources and Vulnerability, Ministry of Marine Affairs and Fisheries, West Sumatra, 25245, Republic of Indonesia
}

\begin{abstract}
Research Institute for Coastal Resources and Vulnerability, Ministry of Marine Affairs and Fisheries, has been conducting multidisciplinary researches on vulnerability of shipwreck sites in Indonesian waters since 2011. Shipwreck sites in Indonesia are vulnerable to natural and human factors that threaten their preservation. The identified natural threats include natural disasters and processes such as earthquake, tsunami, volcanic activity, ocean dynamics, extreme weather and coastline changes. Meanwhile, human disturbances that endanger the sites are treasure hunting, metal scavenging, fishing, development programmes such as clearing sea lanes and port development, as well as mass tourism activities. Some shipwrecks are also susceptible to marine litters and oil spills.
\end{abstract}

Keywords: Human disturbances, multidisciplinary research, natural threats, shipwreck, site vulnerability.

\section{Introduction}

SHIPWRECK sites are highly vulnerable and can be easily damaged through direct and indirect contact. According to Flemming ${ }^{1}$ all over the world underwater archaeological sites are vulnerable to variety of damages caused by natural events and human activity. Damages to the shipwreck caused by humans is not as dramatic as the damages caused by natural events, this damage is cumulative and significant ${ }^{2}$. According to a recent UNESCO document (n.d. para 3) maritime heritage sites worldwide are severely damaged by human activities such as commercial exploration and pillaging activities. The International Committee on Underwater Cultural Heritage (ICUCH) (n.d.) is seriously concerned that, increasingly the shipwreck sites are subject to rapid development, natural calamitous events (such as erosion) and underwater biological factors. The excessive use of coastal regions for trawling, dredging, offshore oil and gas explorations and port construction are major threats to preservation of shipwreck sites ${ }^{3}$. Further, maritime heritage is endangered by commercial exploitation, diving activities and fishing practices, which use advanced technological tools ${ }^{4}$. In

*e-mail: niahasanah79@gmail.com
Indonesia, shipwreck sites are vulnerable because of large scale fishing, pillaging of artefacts and metal scavenging.

This article discusses the vulnerability of Indonesian shipwreck sites. Preservation of shipwreck sites is critical for reconstruction of maritime history of the archipelago. Underwater surveys in the waters of the Indonesian archipelago have brought to light the largest number of shipwreck sites anywhere in the world. They belong to several periods of Indonesian maritime history. Owing to the vast seawater areas, with 17,508 islands, and the complexity of vulnerability issues, managing the underwater heritage has become a stupendous task and a major cause for concern.

\section{Multidisciplinary research on vulnerability of shipwreck sites}

In Indonesia, there is a steady progress of multidisciplinary research on shipwreck vulnerabilities. The Ministry of Marine Affairs and Fisheries (MMAF) through the Research Institute for Coastal Resources and Vulnerability (RICRV) regularly assesses the condition of shipwreck sites and evolves suitable strategies to preserve and protect the sites. A vulnerability assessment is carried out to identify and assign shipwreck sustainability or preservation using a risk-based approach. There are three primary objectives of vulnerability research:

(1) Identify vulnerabilities ranging from direct natural and human threats to indirect threats.

(2) Document the vulnerabilities so that an institution can easily identify the threats and the findings.

(3) Create guidance to assist policy makers and other stakeholders to overcome problems relating to the preservation of shipwreck sites based on the identified vulnerabilities so that they can initiate necessary measures.

Multidisciplinary research involves teams of experts specialized in marine archaeology, oceanography, marine geology, GIS, geophysics, marine ecosystem and tsunami experts. Research activities include: (a) literature review; (b) field surveys to obtain data regarding shipwreck deterioration and the extent of damage; (c) interviewing local communities, local government and relevant stakeholders to obtain data and information on the weather and climate conditions, shipwreck history and tourism industry development; (d) obtaining data from marine geology, 
ocean hydrodynamics and bathymetry; (e) collecting meteoric-climate data; and (f) remote sense data on coastal changes in the region of shipwreck sites.

\section{Identified shipwreck sites vulnerabilities in Indonesia}

\section{Earthquake and tsunami}

When Mentawai Island in west Sumatra was hit by earthquake and tsunami in 2009-2010, the shipwreck likely from the Verenigde Oostindische Compagnie (VOC) period was drawn to the surface. Before the earthquake and tsunami, the shipwreck was located at a depth of $8 \mathrm{~m}$ depth and consequently the wreckage was lifted to shallower waters at a depth of 2-3 m. Following this event, the shipwreck was visible to plunderers. Unfortunately plundering was carried out by fishermen and the personnel of the local government. It also came to light that plundering was supported by a foreign treasure hunter company based in Hong Kong. By the time a joint team of MMAF and Ministry of Education and Culture of Indonesia launched an investigation (2010-2011), most of the valuable artefacts were looted away. Only a small number of ceramics and metal objects were left behind ${ }^{5}$.

\section{Coastal changes, ocean dynamics and extreme weather due to climate change}

Ocean dynamics triggered by environmental change can pose serious threat to shipwreck sites. In 1943 the United States Army Transport (USAT) Liberty shipwreck at Tulamben village, Bali that was stranded at Tulamben beach was devastated due to strong sea wave erosion. The site is located in an area where robust ocean currents from the Pacific and Indian oceans meet. In 2013, the RICRV carried out investigations to collect data on Liberty's present condition, its history, hydrodynamics of Tulamben waters, coastal erosion and other physical environmental data to identify the potential vulnerabilities threatening the site's sustainability. The USAT Liberty, which is the most popular World War II (WW II) shipwreck site that has been at the centre of attraction for divers in Indonesia and is also well-known throughout the world since the $1980 \mathrm{~s}$, is susceptible to a variety of physical-mechanical damages caused by sea currents and strong winds resulting in erosion, shifting and sliding ${ }^{6}$.

A survey of Tulamben coastline and discussion with the local people provided significant information on coastal changes. Points of observations were selected based on the recommendation of the local people. It was found that nearly $45 \mathrm{~km}$ of the coast has experienced erosion varying from moderate to severe conditions. Seawalls have been constructed to protect many public facilities and coastal villages from wave attack. In the last couple of decades coastal erosion has consumed some parts of the land. Coastal erosion in north-eastern Bali seems to be part of beach cycle evolution ${ }^{7}$. The erosion process has progressively 'dropped' the USAT Liberty, that was originally stranded on the beach, into the ocean on a 60 $90 \%$ slope. It is highly likely that the USAT Liberty will move deeper into the deeper part of the sea. This may help preserve the shipwreck from plunderers.

Climate change is also affecting the Liberty site and its ecosystem. The coral reefs attached to the Liberty have experienced severe bleaching by the El Niño event of 1998 (ref. 8). The RICRV investigation also found that nowadays some coral reefs attached to the hull are also experiencing stress. Tulamben dive guides stated that many species of fish have disappeared from the site, and many coral reefs are damaged and destroyed each time extreme weather conditions occurred in Bali. In 2013, high waves and strong currents caused further damage and many parts of the wreckage crumbled into the sea, especially those parts that were severely corroded.

\section{Volcanic activities}

USAT Liberty destruction in Tulamben was also affected by volcanic activity of Mt. Agung. The Volcanic Discovery (2013) mentioned that volcanic eruption of Mt. Agung in $1808,1821,1843$ and 1963 are believed to have played an important role in shaping the characteristics of the beach in Tulamben ${ }^{9}$. When Mt. Agung erupted in 1963, the tremor of volcanic eruption caused the stranded USAT Liberty to slip down into deeper waters. Due to its location in the subduction zone, land subsidence has also a role in coastal erosion in the north-east Bali. This inference is subject to verification and validation of data.

Based on bathymetric analysis of the site by RICRV it is observed that Liberty's position is located on a fairly steep slope. The wreck section found at the shallower part is about $4 \mathrm{~m}$, and the deepest is at $35 \mathrm{~m}$. After this depth, the seafloor around Liberty becomes deeper up to $75 \mathrm{~m}$. Onset of either volcanic eruption or earthquake in the area is likely to pull down the shipwreck to $75 \mathrm{~m}$ depth of the sea bottom. Such features are likely to affect the socio-economic conditions and livelihood of local people (Figure 1).

\section{Treasure hunting}

Treasure hunting in Indonesian waters is rampant and a major cause for concern. Since the 1980s, Indonesia has become a paradise for treasure hunters. The best examples are those of VOC shipwreck, De Geldermalsen (Nanking Cargo) in 1985 and Gelasa Strait shipwreck (Tek Sing Cargo) in 1999. The loot was masterminded by Michael Hatcher. Hatcher salvaged the cargoes of Geldermalsen and auctioned off at Christies in the Netherlands for 
US\$ 17 million. In 2010, Michael Hatcher was seen again in the Blanakan waters, Subang, West Java Province. He conducted diving activities and carried out surveys using sonar equipment. In the Blanakan waters, Hatcher targeted thousands of underwater artefacts belonging to the Ming Dynasty's porcelain, which were estimated to be worth US\$ 200 million ${ }^{10}$.

Treasure hunting is also committed by local fishermen. Recently, the MMAF conducted a survey on a VOC shipwreck site in Karang Bui, Karawang-Subang waters in West Java and found that local fishermen had looted the site and removed artefacts consisting of VOC era coins and Dutch colonial government coins, metal artefacts and ceramic fragments. They admitted that the total weight of the looted coins was 1 tonne and $15 \mathrm{~kg}$ valued at a price of IDR 100,000 (US\$ 7.7) per $\mathrm{kg}^{11}$. These coins belonged to 1624, 1729 and $1835 \mathrm{CE}$ (Figure 2).

\section{Metal scavenging}

Shipwreck looting activities are not only limited to scavenging artefacts or treasure but also to salvaging the metal body parts. Metal scavenging in Indonesia is committed by local fishermen, small-scale scrap metal looters and large companies using large ships and barge crane with sophisticated machines for dredging the seafloor to lift the entire wreck of a warship. In recent years there is alarming increase in large scale plundering of metal parts of WW II shipwrecks.

The loss and destruction of WW II wrecks in the Java Sea and Sunda Strait became a serious issue and attracted

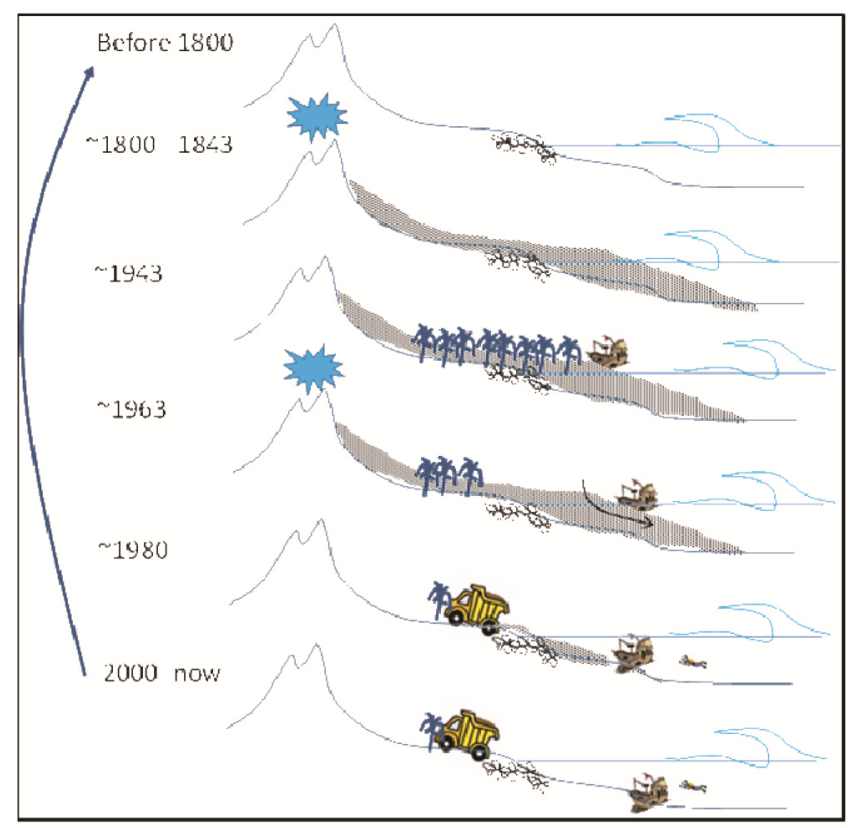

Figure 1. Coastal evolution of Tulamben beach and the chronology of the sliding process of USAT Liberty into her current position. (Research Institute for Coastal Resources and Vulnerability). action of the related countries such as the Netherlands, UK, USA and Australia. Three WWII Dutch ships HNLMS De Ruyter, HNLMS Java and HNLMS Kortenaer are believed to have vanished from the Java Sea along with the US submarine, USS Perch, and British warships, HMS Exeter, HMS Electra and HMS Encounter. Metal scavenging is also faced by the Ashigara shipwreck which was a heavy cruiser of Imperial Japanese Navy, Seven Skies, and Igara shipwreck sites in Anambas waters.

Preliminary investigations by MMAF and other institutions have revealed that salvaging activities were undertaken by a large foreign flagged vessel such as MV Chuan Hong 68 which plundered Seven Skies and Igara. This Chinese flagged ship has also illegally salvaged the wrecks of Sagiri, Hiyoshi Maru and Katori Maru. In a joint operation between Indonesian government, Malaysia and Interpol, Chuan Hong 68 was captured in East Johor, Malaysia. In the Ashigara case, it is presumed that the foreign-flagged vessel had cooperation with local company to misuse the government permit to salvage Ashigara using the reason of clearing the seafloor in shipping lines $^{12}$.

\section{Marine litters}

The presence of marine litters at shipwreck sites at certain times can be seen at the location of HMAS Perth and USS Houston, at Banten Bay. These are the historic shipwrecks of WW II. In 2015, the RICRV team observed a large amount of marine litter gathered on HMAS Perth. The garbage was moved by underwater currents and circled around the HMAS Perth site for approximately $1 \mathrm{~h}$. The litters came from the tip of Banten Bay in the west side. The litters disappeared with the current movement to the inner of the Banten Bay. The modelling of the

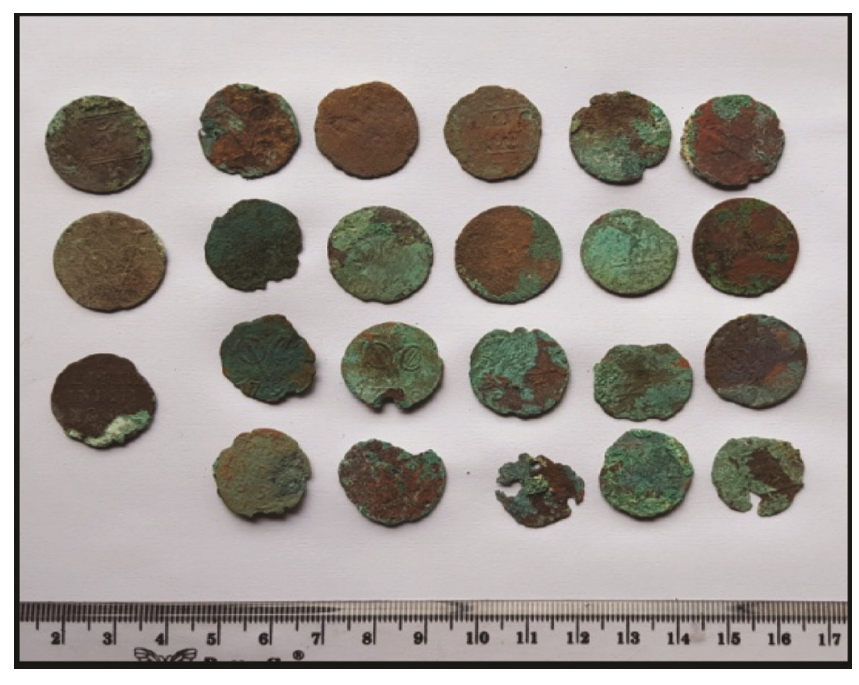

Figure 2. VOC Coins discovered from Karang Bui Site, Karawang Subang waters. (Nia Naelul Hasanah Ridwan). 
movements of the trajectory of marine litters and the current showed that marine litters do indeed pass through the locations of HMAS Perth and USS Houston shipwrecks at certain times (Figure 3$)^{13}$.

The phenomenon of marine debris found at the locations of HMAS Perth and Houston wrecks is very alarming because these two sites are war graveyards and are the intended destination of people performing a flower sowing ceremony for 375 crew members of HMAS Perth and 696 of USS Houston who died in the battle of Sunda Strait, which was the second largest sea battle in Indonesia after the battle of the Java Sea and considered as one of the biggest naval battles during WW $\mathrm{II}^{14}$.

\section{Oil spill}

Shipwreck sites located at sea and in coastal areas are vulnerable to oil spill disasters. In the Indonesian waters the SS Aquila shipwreck in Teluk Ambon, Moluccas Island, which sank on 27 May 1958, was subject to oil spill disaster. Today SS Aquila is well-known as a dive site among the local and international divers. The oil spill problem in this area is caused by the explosion of MV Fu Yuan 66 in 2005. The prevention action was done by the local people using an oil boom net. However, this effort did not really work in reducing the impact of oil spill. In addition, the ship's activities in Wayame Port in Ambon Bay also increases the oil concentration in this area. This condition which is also supported by the weak water mass dynamics can result in the deposition of the spilled oil. All or part of sea water in the area is subject to pollution and affects the sustainability of the SS Aquila site and causes corrosion of the shipwreck, disruption of marine tourism and harm marine biota in the surrounding area.

In the warm tropical sea water, the corrosion of metal is faster due to the support of encrusting organism's

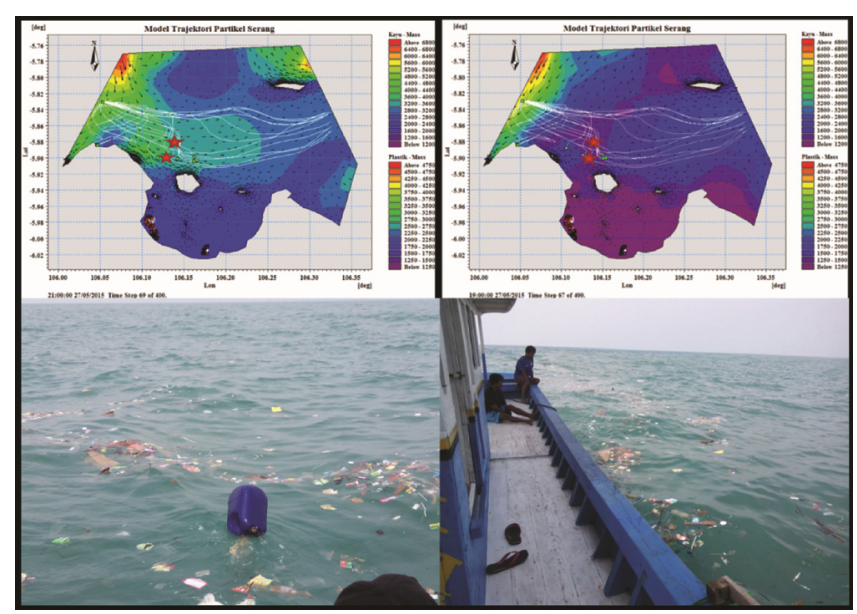

Figure 3. Marine litters and modelling result of marine litters trajectory on HMAS Perth shipwreck site in Banten Bay (Research Institute for Coastal Resources and Vulnerability). encapsulation such as bryozoans, corals and coralline algae. The occurrence of oil spill aggravates the corrosion issue. The intake of the oil spill at Ambon Bay is, undoubtedly threatening the preservation of SS Aquila and its marine environment and disrupting the development of marine heritage utilization ${ }^{15}$.

\section{Underwater mass tourism}

Underwater mass tourism activities can make shipwreck sites vulnerable to damage, especially physical and chemical damage. Mass tourism for underwater sites that can be found in Indonesia is at the Liberty site, Tulamben, Bali. During 2013-2014, around 70,000 tourists dived at the site. This is very much different when compared to the SS Yongala site in the Great Barrier Reef, Australia which limits the number of divers to 7000/year. Today, the number of divers in Tulamben has reached 300-400 per day, and this number is increasing every year ${ }^{16}$. Larger the number of divers, greater is the physical damage to the shipwreck. Many beginners with limited diving skill and reckless behaviour, uncontrolled flapping of fins, arbitrary penetration into the hull and holding a fragile ship body can cause damage to Liberty and its ecosystem. Besides physical damage, the concentration of oxygen from air released by divers may transform into air pockets trapped in the ship's hull. This accelerates the oxidation process, which increases the corrosion level and also accelerates the chemical destruction process.

\section{Development programme}

The issue of balancing conservation efforts on underwater cultural heritage, with economic development in the coastal zone has emerged in some countries. Evans et $a{ }^{3}{ }^{3}$, emphasized that the challenge is to balance the protection of the underwater cultural heritage without denying or unfairly restricting the economic development of the coastal zone. Development activities in the sea and coastal areas in Indonesia often intersect with the preservation of shipwreck sites. The government's efforts to clean the sea lanes and areas around the port where there are many shipwrecks, in the waters of Bangka Belitung and eastern Sumatra waters is a good example. At present there are allegations that a number of ships have misused permits obtained from the Indonesian government to simultaneously carry out illegal actions to salvage WW II shipwrecks.

In the Banten Bay region, there is a sea sand mining location that is very close to the location of the HMAS Perth and the USS Houston. The zoning area is officially determined by the local government. However, currently the zoning for the sea sand mining site has been shifted by the local government because the HMAS Perth has been officially designated as a maritime conservation 
area. Meanwhile, the USS Houston is in the process of being declared a heritage site.

In 2013-2014, on the Weh Island, Banda Aceh Province, there was a case of MS Sophie Rickmers shipwreck site. This was a German steam engine ship built in 1920, which faced a threat to its sustainability. The Sabang city government submitted a letter requesting permission to appoint a commercial salvage company to lift the cargo of Sophie Rickmers to the National Committee of Valuable Objects from Sunken Ship ${ }^{17}$. In addition, there was an issue that the local government planned to build an underwater oil bunker at the location of Sophie Rickmers to service large ships in the shipping industry. The plan to lift the cargo ship and the construction of oil bunker provoked a strong reaction from the local community, local non-governmental organizations. This community reaction led to the signing the 'Save Sophie' petition that was signed by 15,043 people in 2014 , and the petition was then sent to the Minister of Marine Affairs and

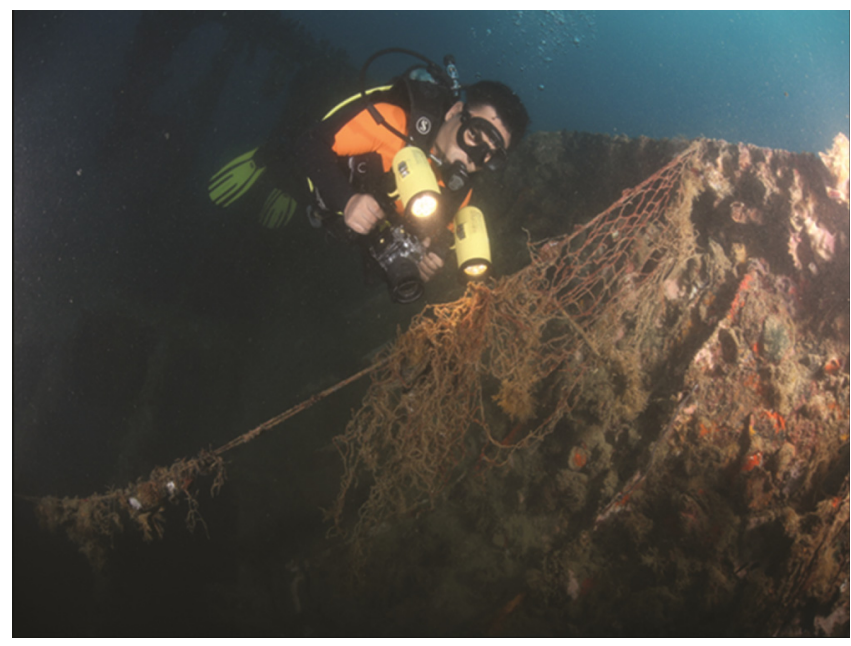

Figure 4. Fishing net found on MV. Boelongan Nederland shipwreck site (Research Institute for Coastal Resources and Vulnerability).



Figure 5. Fishing net found on USS Houston shipwreck site (Research Institute for Coastal Resources and Vulnerability).
Fisheries. Eventually, the minister rejected the application for the salvage of Sophie Rickmers' cargo based on the Ministerial Regulation on the Moratorium on permits for surveying and salvaging the cargo ${ }^{18}$.

\section{Fishing activities}

Shipwrecks in Indonesia are also quite vulnerable to fishing activities. Fishing activities which include anchoring have damaged the integrity of the wreck, for example such activities at MV Boelongan Nederland shipwreck site at Mandeh Bay, West Sumatra ${ }^{19}$. While fishing, the anchors are moored to the body of the wreck which is $17-$ $28 \mathrm{~m}$ deep. While installing and pulling anchors, the wreck suffers greater damage. Fishing activities using large nets have also damaged the wreck causing breaking of fragile parts. Many fishing nets are found at Boelongan Nederland site and the USS Houston site at Banten Bay (Figures 4 and 5).

\section{Summary}

The shipwreck site preservation is affected by both natural and human factors. Shipwreck sustainability depends on appropriate management strategies and the shared commitment of all stakeholders. The management of shipwreck sites demands a holistic approach. The Indonesian government needs to provide resources for ongoing monitoring work to ensure shipwreck sites are prevented from threats. Plundering problems undoubtedly require a considerable attention of the Indonesian government, public and international community. International cooperation and public awareness programmes should be encouraged. Long-term measures and monitoring are necessary for identifying the vulnerability of shipwreck sites.

1. Flemming, N., The compatibility of heritage protection and development projects. In UNESCO Scientific Colloquium on Factors Impacting Underwater Cultural Heritage, UNESCO Regional meeting on the protection of the underwater cultural heritage: conference book Royal library of Belgium, Brussels, 2012, pp. 51-59.

2. Viduka, A., Managing underwater cultural heritage: a case study of the SS Yongala. Hist. Environ., 2011, 23(2), 12-18.

3. Evans, A. M., Firth, A. and Staniforth, M., Old and new threats to submerged cultural landscapes: fishing, farming and energy development. Conserv. Manage. Archaeol. Sites, 2009, 11(1), 4353.

4. Zamora, T. V., The impact of commercial exploitation on the preservation of underwater cultural heritage. Museum Int., 2008, 60(4), 18-30.

5. Ridwan, N. N. H., Kasus pengangkatan ilegal peninggalan bawah air di Kepulauan Mentawai. Varuna J. Arkeologi Bawah Air, 2014, 8, 126-144 (in Indonesia).

6. Ridwan, N. N. H., Husrin, S. and Kusumah, G., USAT Liberty shipwreck site in Tulamben, Karang Asem Regency, Bali is under threats. In Proceedings of the 2nd Asia-Pacific Regional 
Conference on Underwater Cultural Heritage (eds Tilburg, et al.), Honolulu, Hawaii, 2014, vol. 2, pp. 881-893.

7. Husrin, S., Pratama, R., Putra, A., Sofyan, H., Ridwan, N. N. H., Yuanita, N. and Meilano, I., The mechanism of coastal erosion in Northeast Bali. J. Segara, 2016, 12(2), 109-120 (in Indonesia).

8. Pickell, D. and Wally, S., Diving Bali: the underwater jewel of Southeast Asia, Periplus, Singapore, 2010, pp. 17-232.

9. Volcano Discovery, Agung Volcano, World Volcano Database, 2013; www.volcanodiscovery.com/volcanoes/indoensia/bali/agung/.

10. Marbun, J., An advocacy approach on underwater heritage in Indonesia, case study: an auction on underwater heritage from Cirebon waters in 2010. In Proceedings of the Asia-Pacific Regional Conference on Underwater Cultural Heritage (eds Staniforth, M. et al.), Manila, 2011, pp. 565-574.

11. Ridwan, N. N. H., Gemilang, W. A., Wisha, U. J. and Rahmawan, G. A., Survei situs benda berharga asal muatan kapal tenggelam di Perairan Karawang-Subang. Final Research Report, Padang, Research Institute for Coastal Resources and Vulnerability, 2017, pp. 1-53 (In Indonesia).

12. Ridwan, N. N. H. and Kusumah, G., Surveying a World War II German ship, MS Sophie Rickmers in Weh Island, Indonesia: a preliminary report. In Proceedings of the 3rd Asia-Pacific Regional Conference on Underwater Cultural Heritage (eds Fahy, B. et al.), Hong Kong, 2017, pp. 1080-1092.

13. Ridwan, N. N. H., Husrin, S. and Kusumah, G., Riset potensi sumber daya arkeologi maritim di Provinsi Banten. Final Research Report, Padang, Research Institute for Coastal Resources and Vulnerability, 2015, pp. 1-121 (in Indonesia).

14. Whiting, B., Ship of Courage: The Epic Story of HMAS Perth and Her Crew, Allen and Unwin Pty, Ltd, Australia, 1995.

15. Wisha, U. J., Rahmawan, G. A., Ridwan, N. N. H. and Kusumah, G., Oil spill analysis on Ambon Bay, Moluccas, Indonesia: its influence on SS Aquila shipwreck site. In Proceedings of the 23rd Asia-Pacific Regional Conference on Underwater Cultural Heritage (eds Fahy, B. et al.), Hong Kong, 2017, pp. 846-857.

16. Ridwan, N. N. H., Maritime Archaeology in Indonesia: resources, threats, and current integrated research. J. Indo-Pacific Archaeol., 2015, 36, 16-24.

17. Husein, N., Save Sophie, petisi untuk Bu Susi selamatkan kapal Sophie Rickmers, 2014; http://www.mongabay.co.id/2014/11/18/ savesophie-petisi-untuk-bu-susi-selamatkan-kapal-sophie-rickmers/ (in Indonesia).

18. Mangalandum, R. S., She is indeed our Sophie Rickmers! story of a historical shipwreck, 2014; https://minutes4bahari.wordpress. com/2014/12/07/103/.

19. Ridwan, N. N. H. and Putra, A., Pengembangan situs kapal karam MV Boelongan Nederland di kawasan wisata bahari terpadu Mandeh. In Bunga rampai Sumatera: Silang budaya kontestasi nilai-nilai historis, arkeologis, dan antropologis serta upaya pelestarian cagar budaya (ed Sri Sugiharta), Balai Pelestarian Cagar Budaya Batu Sangkar, Batu Sangkar, 2017, pp. 443-448 (in Indonesia).

ACKNOWLEDGEMENTS. I thank the research team at Research Institute for Coastal Resources and Vulnerability, Directorate of Marine Services and also the local government of Pesisir Selatan Regency, Karang Asem Regency and Banten Province for their support and assistance.

doi: $10.18520 / \mathrm{cs} / \mathrm{v} 117 / \mathrm{i} 10 / 1623-1628$ 